\title{
Kedudukan dan Kewenangan Dewan Perwakilan Daerah dalam Sistem Ketatanegaraan Indonesia
}

\author{
Salmon E.M. Nirahua \\ Fakultas Hukum Universitas Pattimura \\ Jl. Ir. M. Putuhena Poka-Ambon \\ monnirahua@yahoo.com
}

\begin{abstract}
Functioned as a regional representative council, DPD possessing a regional representative character principally has a broader representative character compared to DPR (Legislative Assembly). It is because its representative dimensions are based on all of the citizens living in the regions. The issues being studied include (1) Is the existence of DPD in line with the idea of its establishment based on the bicameral legislative system?, (2) Is the constitutional authority of DPD synchronic with its existence as a state institution? This is a normative research focused on primary and secondary materials of law including the regulation of law and the literatures relevant as the research object. In obtaining the primary and secondary materials, a library research was conducted by involving a descriptive-qualitative analysis. The research result then shows the existence of DPD in relationship with DPR and MPR as regulated in the Constitution of 1945 is not in line with the thought of its establishment. At this point, the reform on the structure of Indonesia Constitution toward a strong bicameralism is not materialized in the Constitution of 1945. .
\end{abstract}

Key words : Existence of DPD, authority of DPD, system of Indonesia constitutional

\begin{abstract}
Abstrak
DPD selaku lembaga perwakilan daerah yang memiliki karakter keterwakilan berdasarkan daerahdaerah pada hakikatnya memiliki karakter keterwakilan yang lebih luas dari DPR, karena dimensi keterwakilannya berdasarkan seluruh rakyat yang terdapat pada daerah-daerah tersebut. Masalah yang diteliti, pertama, apakah kedudukan DPD sesuai dengan gagasan pembentukan DPD berdasarkan sistem perwakilan bikameral? Kedua, apakah kewenangan konstitusional DPD sinkron dengan kedudukan DPD sebagai lembaga negara? Penelitian ini merupakan penilitian normatif yang mendasarkan pada bahan hukum primer dan sekunder, yang berupa peraturan perundang-undangan dan literatur-literatur yang relevan dengan objek penelitian. Bahan hukum primer dan sekunder diperoleh melalui studi kepustakaan. Analisis yang digunakan dalam penelitian ini adalah diskriptif kualitatif. Hasil penelitian menyimpulkan dalam hubungannya dengan DPR dan MPR, kedudukan DPD sebagaimana diatur dalam UUD 1945 tidak sesuai dengan gagasan pembentukan DPD. Reformasi struktur ketatanegaraan Indonesia menuju sistem perwakilan bikameral yang kuat (strong bicameralism) tidak terwujud dalam UUD 1945.
\end{abstract}

Kata kunci : Kedudukan DPD, kewenangan DPD, sistem ketatanegaraan Indonesia 


\section{Pendahuluan}

Tuntutan reformasi melalui perubahan Undang-Undang Dasar 1945 telah mengakibatkan terjadinya perubahan dalam sistem ketatanegaraan Indonesia. Salah satu perubahan tersebut terjadi dalam kelembagaan negara dengan bertambahnya lembaga Dewan Perwakilan Daerah (selanjutnya disebut DPD). Perubahan Ketiga Undang-Undang Dasar 1945 yang dilaksanakan pada tahun 2001 dalam Sidang Tahunan Majelis Permusyawaratan Rakyat Republik Indonesia, secara yuridis sebagai dasar kehadiran lembaga baru dalam sistem ketatanegaraan di Indonesia yaitu Dewan Perwakilan Daerah Republik Indonesia yang diatur dalam Pasal 22C dan Pasal 22D. Sebagai tindaklanjut dari Pasal 22C dan Pasal 22D Undang-Undang Dasar Negara Republik Indonesia Tahun 1945, pengaturan dalam peraturan perundang-undangan yang berkaitan dengan DPD diatur dalam Undang-Undang Nomor 27 Tahun 2009 tentang Majelis Permusyawaratan Rakyat, Dewan Perwakilan Rakyat, Dewan Perwakilan Daerah dan Dewan Perwakilan Rakyat Daerah.

Kehadiran DPD sebagai lembaga baru hasil perubahan Undang-Undang Dasar Negara Republik Indonesia Tahun 1945 (selanjutnya disebut UUD 1945) merupakan konsekuensi dari perubahan Pasal 1 ayat (2) sebagai upaya untuk mengoptimalkan dan meneguhkan paham kedaulatan rakyat. Hal ini terjadi karena paham kedaulatan rakyat selama ini melalui Majelis Permusyawaratan Rakyat (selanjutnya disebut MPR) sebagai pemegang kedaulatan rakyat telah disalahgunakan. ${ }^{1}$ Perubahan Pasal 1 ayat (2) UUD 1945 ini pun dengan sendirinya menegaskan bahwa MPR bukan satu-satunya yang melaksanakan kedaulatan rakyat. ${ }^{2}$ Rumusan Pasal 1 ayat (2) UUD 1945 menyebutkan bahwa: “Kedaulatan adalah di tangan rakyat, dan dilakukan menurut Undang-Undang Dasar". Rumusan tersebut di atas dimaksudkan bahwa kedaulatan rakyat yang pelaksanaannya diserahkan kepada badan/lembaga yang keberadaan, wewenang, tugas dan fungsinya ditentukan oleh UUD 1945 itu serta

\footnotetext{
${ }^{1}$ Perubahan Pasal 1 ayat (2) Undang-Undang Dasar Negara Republik Indonesia Tahun 1945 merupakan konsekuensi dari kedudukan Majelis Permusyawaratan Rakyat (MPR) yang dikukuhkan sebagai Lembaga Tertinggi Negara yang dianggap merupakan penjelmaan kedaulatan rakyat. Melalui kekuasaan yang besar dari MPR, maka dalam praktek-praktek ketatanegaraan yang terjadi selama ini (sebelum perubahan UUD) tidak jarang penggunaannya diselewengkan sebagai sarana memperbesar kekuasaan Presiden di luar ketentuan Undang-Undang Dasar 1945. Dapat dicatat, bahwa pada masa Orde Lama, MPR telah dipakai untuk memperkukuh ideologi Manipol Usdek dan menyatakan Presiden Soekarno sebagai presiden seumur hidup. Selain itu dalam masa Orde Baru pun melalui MPR telah terjadi pemberian kekuasaan tidak terbatas kepada Presiden melalui Ketetapan MPR Nomor V/MPR/1998 tentang Pemberian Tugas dan Wewenang Khusus Kepada Presiden/Mandataris MPR Republik Indonesia Dalam Rangka Penyuksesan dan Pengamanan Pembangunan Nasional Sebagai Pengamalan Pancasila.

${ }^{2}$ Bagir Manan, Perkembangan Undang-Undang Dasar 1945, FH UII Press, Yogyakarta, hlm. 53.
} 
bagian mana yang langsung dilaksanakan oleh Rakyat. Dengan kata lain, pelaksanaan kedaulatan rakyat tidak diserahkan kepada badan/lembaga mana pun, tetapi langsung dilaksanakan oleh rakyat itu sendiri melalui pemilu. ${ }^{3}$ Implementasi dari prinsip kedaulatan rakyat di atas, maka dilakukan dalam bentuk pemilihan langsung bagi anggota DPD.

DPD sebagai salah satu lembaga perwakilan selain Dewan Perwakilan Rakyat (selanjutnya disebut DPR) tidak dapat dilepaskan dan merupakan tuntutan dari terselenggaranya sistem penyelenggaraan pemerintahan daerah yang lebih mengedepankan asas otonomi dan tugas pembantuan. Hal ini dapat dilihat dalam Perubahan Kedua UUD 1945 pada Pasal 18, Pasal 18A, dan Pasal 18B yang memberikan penekanan penyelenggaraan pemerintahan daerah dan hubungan pusat dan daerah dilaksanakan dengan sistem otonomi luas. Untuk menjaga dan menindaklanjuti kepentingan daerah dalam pengambilan kebijakan di pusat, maka diperlukan lembaga yang memiliki eksistensi dan kedudukan serta fungsi yang dapat menjembatani kepentingan daerah. Dengan didasarkan pada pengalaman dalam perjalanan sistem ketatanegaraan Indonesia, dapat dilihat bahwa utusan daerah sebagai perwakilan daerah di MPR pun tidak dapat melakukan fungsi tersebut, dan melalui tuntutan adanya restrukturisasi kelembagaan MPR, maka diperlukan lembaga perwakilan yang berkaitan denga kepentingan daerah yang dirumuskan sebagai DPD.

Adanya DPD sebagai lembaga legislatif tersendiri selain DPR, maka susunan MPR mengalami perubahan dari susunan sebelum perubahan Undang-Undang Dasar 1945 yang terdiri dari anggota DPR ditambah utusan daerah dan golongan-golongan. Oleh Philipus M. Hadjon, dikatakan bahwa perubahan ketiga dan keempat membawa konsekuensi fundamental terhadap kedudukan dan fungsi MPR. Dalam perubahan ketiga, dilakukan perubahan terhadap ketentuan Pasal 1 ayat (2) dan Pasal 3 UUD 1945. Perubahan terhadap Pasal 1 ayat (2) UUD 1945 telah menggusur doktrin supremasi MPR yang telah menjadikan MPR sebagai Lembaga Tertinggi Negara secara inskonstitusional. Dalam perubahan keempat, dilakukan perubahan terhadap ketentuan Pasal 2 ayat (1) Undang-Undang Dasar 1945. Perubahan tersebut merubah secara mendasar susunan MPR. MPR yang semula terdiri atas anggota

${ }^{3}$ Panduan Pemasyarakatan Undang-Undang Dasar Negara Republik Indonesia Sesuai dengan Urutan Bab, Pasal, dan Ayat, Sekretariat Jenderal MPR RI, 2005, hlm. 44-45. 
DPR, ditambah utusan-utusan dari daerah dan golongan-golongan, menjadi MPR yang terdiri atas anggota DPR dan anggota DPD. ${ }^{4}$

Secara umum, perubahan UUD 1945 dengan kehadiran DPD telah mewujudkan sistem perwakilan dua kamar (bikameral) dalam sistem ketatanegaraan Indonesia. Terhadap hal tersebut, maka menimbulkan ketidakpastian secara yuridis berkaitan dengan sistem perwakilan dua kamar (bikameral). Padahal gagasan pembentukan DPD sebagai upaya restrukturisasi parlemen di Indonesia dengan sistem bikameral. Hal ini pula yang menimbulkan pertanyaan secara berkaitan dengan kedudukan DPD dalam sistem ketatanegaraan Indonesia berdasarkan UUD 1945.

Dalam sistem ketatanegaraan Indonesia saat ini, DPD memiliki kedudukan yang tidak jelas. Apalagi pengaturan dalam UUD 1945 yang berkaitan dengan DPD tidak diatur secara komprehensif dan sangat sumir sebagaimana tertuang dalam Pasal 22C, Pasal 22D, Pasal 23E ayat (1), dan Pasal 22F ayat (2) ataupun berdasarkan Undang-Undang Nomor 27 Tahun 2009. DPD sama sekali tidak memiliki kekuasaan apapun, selain hanya memberikan pertimbangan, usul, ataupun saran kepada DPR sebagai lembaga yang memutuskan, baik dalam bidang legislatif maupun pengawasan. Kewenangan DPD berkaitan dengan penyelenggaraan otonomi daerah yang sebatas memberikan pertimbangan pun menampakkan kelemahan fungsi DPD karena tidak dapat memperjuangkan kepentingan daerah dan sebagai lembaga bargaining terhadap kemungkinan pertimbangan DPD yang tidak dilanjuti oleh DPR. Apalagi rancangan undang-undang yang tidak sesuai dengan kepentingan daerah tidak dapat dibatalkan oleh DPD dengan menggunakan hak veto, sebagaimana dipraktikkan dalam sistem perwakilan bikameral. Hal inilah yang mengakibatkan DPD tidak memiliki kekuasaan sama sekali dalam sistem ketatanegaraan saat ini yang membuat kedudukan DPD sangat lemah bahkan hanya sebagai lembaga yang hanya memberikan pertimbangan kepada DPR.

\section{Rumusan Masalah}

Berdasarkan uraian latar belakang masalah tersebut di atas, maka yang menjadi rumusan masalah dalam penulisan ini adalah sebagai berikut: 1. apakah kedudukan

${ }^{4}$ Philipus M. Hadjon, "Eksistensi, Kedudukan, dan Fungsi MPR Sebagai Lembaga Negara Dalam Sistem Ketatanegaraan Republik Indonesia”, Makalah Seminar Peran MPR-RI Pasca Amandemen UUD 1945, yang dilaksanakan oleh Sekretariat Jenderal MPR-RI bekerjasama dengan Fakultas Hukum Universitas Airlangga, di Surabaya, 22 Desember 2005, hlm. 1 
DPD sesuai dengan gagasan pembentukan DPD berdasarkan sistem perwakilan bikameral? 2. apakah kewenangan konstitusional DPD sinkron dengan kedudukan DPD sebagai lembaga negara?

\section{Tujuan Penulisan}

Penelitian ini bertujuan untuk, 1. mengkaji dasar normatif kewenangan konstitusional Dewan Perwakilan Daerah dalam sistem perwakilan bikameral; 2. mengkaji apakah kewenangan konstitusional DPD sinkron dengan kedudukan DPD sebagai lembaga negara.

\section{Metode Penelitian}

Penelitian ini merupakan penelitian hukum normatif, yakni suatu penelitian yang terutama mengkaji ketentuan-ketentuan hukum positif, asas-asas hukum, prinsipprinsip hukum maupun doktrin hukum guna menjawab isu hukum yang dihadapi. pendekatan yang digunakan dalam penelitian ini adalah pendekatan peraturan perundang-undangan (statute approach), dan pendekatan konseptual (conceptual approach).Bahan-bahan penelitian berupa bahan hukum primer dan bahan hukum sekunder. Bahan hukum primer dan bahan hukum sekunder yang telah dikumpulkan (inventarisasi), kemudian dikelompokkan. Hal ini kemudian dikaji dengan pendekatan perundang-undangan untuk memperoleh gambaran taraf sinkronisasi dari semua bahan hukum. Bahan hukum yang telah diklasifikasi dan disistimatisasi tersebut dipelajari, dikaji dan dibandingkan dengan teori dan prinsip hukum yang dikemukakan oleh para ahli, untuk akhirnya dianalisis secara normatif.

\section{Hasil dan Pembahasan}

\section{Kedudukan Dewan Perwakilan Daerah dan Gagasan Sistem Perwakilan Bikameral}

Dewan Perwakilan Daerah (DPD) memiliki dasar konstitusional dalam Pasal 22C dan Pasal 22D UUD 1945. Dalam Pasal 22C dan Pasal 22D UUD 1945 mengatur tentang eksistensi, kedudukan dan fungsi DPD. Pasal 22C menyebutkan bahwa:

(1) Anggota Dewan Perwakilan Daerah dipilih dari setiap provinsi melalui pemilihan umum. 
(2) Anggota Dewan Perwakilan Daerah dari setiap provinsi jumlahnya sama dan jumlah seluruh anggota Dewan Perwakilan Daerah itu tidak lebih dari sepertiga jumlah anggota Dewan Perwakilan Rakyat.

(3) Dewan Perwakilan Daerah bersidang sedikitnya sekali dalam setahun.

(4) Susunan dan kedudukan Dewan Perwakilan Daerah diatur dengan undangundang.

Kemudian dalam Pasal 22D ditegaskan:

(1) Dewan Perwakilan Daerah dapat mengajukan kepada Dewan Perwakilan Rakyat rancangan undang-undang yang berkaitan dengan otonomi daerah, hubungan pusat dan daerah, pembentukan dan pemekaran serta penggabungan daerah, pengelolaa sumber daya alam dan sumber daya ekonomi lainnya, serta yang berkaitan dengan perimbangan keuangan pusat dan daerah.

(2) Dewan Perwakilan Daerah ikut membahas rancangan undang-undangan yang berkaitan dengan otonomi daerah; hubungan pusat dan daerah; pembentukan, pemekaran, dan penggabungan daerah; pengelolaan sumber daya alam dan sumber daya ekonomi lainnya, serta perimbangan keuangan pusat dan daerah; serta memberikan pertimbangan kepada Dewan Perwakilan Rakyat atas rancangan undang-undang anggaran pendapatan dan belanja negara dan rancangan undang-undang yang berkaitan dengan pajak, pendidikan, dan agama.

(3) Dewan Perwakilan Daerah dapat melakukan pengawasan atas pelaksanaan undang-undang mengenai; otonomi daerah, pembentukan, pemekaran dan penggabungan daerah, hubungan pusat dan daerah, pengelolaan sumber daya alam dan sumber daya ekonomi lainnya, pelaksanaan anggaran pendapatan dan belanja negara, pajak, pendidikan, dan agama serta menyampaikan hasil pengawasannya itu kepada Dewan Perwakilan Rakyat sebagai bahan pertimbangan untuk ditindaklanjuti.

(4) Anggota Dewan Perwakilan Daerah dapat diberhentikan dari jabatannya, yang syarat-syarat dan tata caranya diatur dalam undang-undang.

Berdasarkan ketentuan di atas yang mengatur kedudukan dan fungsi DPD, memberikan perubahan terhadap sistem perwakilan dalam ketatanegaraan Indonesia yang sebelumnya tidak menampakkan bentuk perwakilan yang sebenarnya. ${ }^{5}$ Dengan kehadiran DPD tersebut, dalam sistem perwakilan Indonesia, DPR didukung dan diperkuat oleh DPD. DPR merupakan lembaga perwakilan berdasarkan aspirasi dan paham politik rakyat sebagai pemegang kedaulatan, sedangkan DPD

${ }^{5}$ Sistem perwakilan dalam praktek ketatanegaraan yang berlaku di dunia, hanya dikenal dua kemungkinan struktur parlemen, yaitu sistem perwakilan satu kamar (unikameral) dan sistem perwakilan dua kamar (bikameral). Struktur ketatanegaraan sebagaimana diatur dalam Pasal 2 ayat (1), tidak mengenal sistem perwakilan bikameral, karena struktur kelembagaan MPR berdiri sendiri selain DPR dan DPD. Hal ini terjadi karena susunan MPR terdiri atas anggota DPR dan anggota DPD, sehingga memberikan kedudukan MPR sebagai lembaga yang terlepas sendiri yang tidak terdiri atas DPR dan DPD sebagai kelembagaan. Dengan struktur MPR seperti ini pun, Indonesia memberlakukan sistem perwakilan yang unik di dunia berupa sistem perwakilan trikameral. Lihat juga Jimly Asshaddiqie, Format Kelembagaan Negara dan Pergeseran Kekuasaan Dalam UUD 1945, FH UII Press, Cet. Kedua, Yogyakarta, 2005, hlm. 275-276. 
merupakan lembaga perwakilan penyalur keanekaragaman aspirasi daerah. Keberadaan lembaga DPD merupakan upaya menampung prinsip perwakilan daerah. ${ }^{6}$ Oleh Jimly Asshiddiqie, unsur anggota DPR didasarkan atas prosedur perwakilan politik (political representation), sedangkan anggota DPD yang merupakan cerminan dari prinsip regional representation dari tiap-tiap daerah provinsi. ${ }^{7}$

Dalam pandangan MPR, pengaturan keberadaan DPD dalam struktur ketatanegaraan Indonesia menurut UUD 1945, antara lain dimaksudkan untuk: 1. memperkuat ikatan daerah-daerah dalam wadah Negara Kesatuan Republik Indonesia dan memperteguh persatuan kebangsaan seluruh daerah; 2. meningkatkan agregasi dan akomodasi aspirasi dan kepentingan daerah-daerah dalam perumusan kebijaksanaan nasional berkaitan dengan negara dan daerah; 3 . mendorong percepatan demokrasi, pembangunan dan kemajuan daerah secara serasi dan seimbang.

Keberadaan daerah sebagaimana dimaksud dalam Pasal 18 ayat (1) dan otonomi daerah sebagaimana dimaksud dalam Pasal 18 ayat (5) berjalan sesuai dengan keberagaman daerah dalam rangka kemajuan bangsa dan negara. ${ }^{8}$

Pasal 22C ayat (4) UUD 1945 menyatakan bahwa: "Susunan dan kedudukan Dewan Perwakilan Daerah diatur dengan undang-undang". Berdasarkan Pasal 22C ayat (4) inilah, maka Undang-Undang Nomor 22 Tahun 2003 sebagaimana telah diubah dengan Undang-Undang Nomor 27 Tahun 2009 yang mengatur lebih jelas berkaitan dengan susunan dan kedudukan DPD.

Pasal 221 menegaskan bahwa "DPD terdiri atas wakil daerah provinsi yang dipilih melalui pemilihan umum". Kemudian dalam Pasal 222 menegaskan bahwa "DPD merupakan lembaga perwakilan daerah yang berkedudukan sebagai lembaga negara. Hal ini apabila dikaitkan dengan Pasal 67 dan Pasal 68 Undang-Undang Nomor 27 Tahun 2009, maka DPD dan DPR memiliki kedudukan yang sama sebagai lembaga negara, sedangkan tingkat keterwakilan yang berbeda sebagai lembaga perwakilan, dimana DPD merupakan lembaga perwakilan daerah, sedangkan DPR merupakan lembaga perwakilan rakyat.

Kedudukan DPD sebagai lembaga negara berkaitan dengan makna kedudukan dari suatu lembaga negara. Oleh Philipus M. Hadjon', yang dimaksudkan dengan

\footnotetext{
${ }^{6}$ Panduan Pemasyarakatan Undang-Undang Dasar ..., Op.Cit., hlm. 93.

${ }^{7}$ Jimly Asshiddiqie, Format Kelembagaan Negara ..., Op.Cit., hlm. 38 dan 49.

${ }^{8}$ Panduan Pemasyarakatan Undang-Undang Dasar ..., Op.Cit., hlm. 93.
} 
kedudukan lembaga negara, pertama kedudukan diartikan sebagai posisi suatu lembaga negara dibandingkan dengan lembaga negara lain, dan aspek kedua dari pengertian kedudukan lembaga negara adalah posisi suatu lembaga negara didasarkan pada fungsi utamanya. Untuk itu, analisis dalam penulisan ini menyangkut kedudukan DPD sebagai lembaga negara, yang dikaitkan dengan pengertian lembaga negara baik dari aspek posisi DPD yang dibandingkan dengan lembaga negara lainnya, terutama MPR. Selain itu pula, kedudukan DPD yang berkaitan dengan fungsi utama dari DPD.

Untuk memahami konsep lembaga negara apabila menggunakan pendekatan perbandingan konsep lembaga negara di Jerman, Konstitusi Jerman membedakan antara state organ dan constitutional organ. Constitutional organ hanyalah menyangkut lembaga-lembaga (organ) yang status dan kewenangannya langsung diatur oleh konstitusi. Sedangkan state organs adalah lembaga-lembaga dalam negara Jerman yang dianggap bertindak atas nama negara Jerman. Dengan perbandingan sistem ketatanegaraan Jerman, hendaklah kita bedakan lembaga-lembaga negara yang status dan kewenangannya langsung diatur oleh UUD dengan lembaga negara yang hanya disebut dalam UUD namun kewenangannya didelegasikan pengaturannya oleh undang-undang. ${ }^{10}$

Menurut Jimly Asshidiqie, ${ }^{11}$ lembaga negara dapat diartikan dalam beberapa pengertian. Pertama, organ negara paling luas mencakup setiap individu yang menjalankan fungsi law-creating dan law-applying; Kedua, organ negara dalam arti luas tetapi lebih sempit dari pengertian pertama, yaitu mencakup individu yang menjalankan fungsi law-creating atau law-applying danjuga mempunyai posisi sebagai atau dalam struktur jabatan kenegaraan atau jabatan pemerintahan; Ketiga, organ negara dalam arti yang lebih sempit, yaitu badan atau organisasi yang menjalankan fungsi law-creating dan/atau law-applying dalam kerangka struktur dan sistem kenegaraan atau pemerintahan; Keempat, organ atau lembaga negara itu hanya terbatas pada pengertian lembaga-lembaga negara yang dibentuk berdasarkan UUD, UU, atau oleh peraturan yang lebih rendah; dan Kelima, untuk memberikan kekhususan kepada lembaga-lembaga negara yang berada di pusat yang

\footnotetext{
${ }^{9}$ Philipus M. Hadjon, Lembaga Tertinggi dan Lembaga-Lembaga Tinggi Negara Menurut Undang-Undang Dasar 1945 Suatu Analisa Hukum dan Kenegaraan, PT Bina Ilmu, Surabaya, 1992, hlm. X.

${ }^{10}$ Philipus M. Hadjon, Ekesistensi, Kedudukan, dan Fungsi MPR...., Op.Cit., hlm. 3-4.

${ }^{11}$ Jimly Asshidiqie, Perkembangan dan Konsolidasi Lembaga Negara Pasca Reformasi, Konstitusi Press, Jakarta, 2006, hlm.40-42.
} 
pembentukannya ditentukan dan diatur oleh UUD 1945, atau disebut sebagai lembaga tinggi negara. Dengan menggunakan konsep-konsep di atas, maka DPD dalam kedudukannya merupakan lembaga negara yang dikategorikan sebagai constitutional organ, karena pengaturan dan kewenangannya langsung diatur oleh UUD 1945.

Untuk memahami kedudukan DPD sebagai lembaga perwakilan yang bersifat bikameral atau tidak, maka dapat dilihat dari hubungan konstitusional kedudukan DPD dengan MPR termasuk di dalamnya pula hubungan antara DPD dengan DPR. Hubungan konstitusional antara kedudukan DPD dengan MPR dapat dilihat dalam Pasal 2 ayat (1), Pasal 3 dan Pasal 8 ayat (2) dan ayat (3) UUD 1945. Hubungan antara DPD dan MPR berdasarkan Pasal 2 ayat (1) merupakan hubungan struktural dimana pengaturannya berkaitan dengan kedudukan anggota DPD sebagai anggota MPR. Pengaturan ini memiliki makna konstitusional bahwa DPD memiliki peran yang sama dengan DPR dalam melaksanakan wewenang MPR. Berdasarkan Pasal 3 dan Pasal 8 ayat (2) dan ayat (3), serta Pasal 37 nampak adanya sinkronisasi antara DPD dan DPR dalam menjalankan wewenang MPR.

Beberapa pasal dalam UUD 1945 yang pengaturannya tidak konsisten dan hubungan yang tidak sinkron dengan kedudukan anggota DPD sebagai anggota MPR sebagaimana diatur dalam Pasal 2 ayat (1) di antaranya, Pasal 7A, Pasal 7B, Pasal 9 ayat (1) dan ayat (2). Dalam Pasal 7A, diatur bahwa Presiden dan Wakil Presiden dapat diberhentikan dalam masa jabatannya oleh MPR atas usul DPR serta dalam Pasal 7B yang mengatur prosedur usul pemberhentian Presiden dan Wakil oleh DPR melalui MPR dan Mahkamah Konstitusi. Sedangkan dalam Pasal 9 ayat (1) dan ayat (2) mengatur sumpah jabatan Presiden dan Wakil Presiden dihadapan MPR atau DPR.

Berdasarkan pengaturan konstitusional yang berkaitan kedudukan DPD menurut UUD 1945, dimana tidak adanya sinkronisasi antara pengaturan pasalpasal dalam UUD 1945, nampak bahwa DPD yang merupakan lembaga perwakilan daerah yang berkedudukan sebagai lembaga negara tidak sesuai dengan gagasan pembentukan DPD dan sistem perwakilan bikameral. Gagasan pembentukan DPD pada hakikatnya untuk memperkuat integrasi bangsa. Alasan keberadaan DPD yang dimaksudkan untuk meningkatkan agregasi dan akomodasi aspirasi dalam konteks perumusan kebijakan nasional bagi kepentingan negara dan daerah-daerah sekaligus merupakan sebuah upaya untuk meningkatkan pemberdayaan daerah dan masyarakat yang ada di seluruh wilayah Indonesia. 
Gagasan pembentukan DPD pun merupakan bagian dari reformasi struktur parlemen Indonesia. Oleh Jimly Asshiddiqie, ${ }^{12}$ semula, reformasi struktur parlemen Indonesia yang disarankan oleh banyak kalangan ahli hukum dan politik supaya dikembangkan menurut sistem bikameral yang kuat (strong bicameralism) dalam arti kedua kamar dilengkapi dengan kewenangan yang sama kuat dan slaing mengimbangi satu sama lain. Untuk itu masing-masing kamar diusulkan, dilengkapi dengan hak veto. Usulan semacam ini berkaitan erat dengan sifat kebijakan otonomi daerah yang cenderung luas dan hampir mendekati pengertian sistem federal. Namun demikian, Perubahan Ketiga UUD 1945 hasil Sidang Tahunan Majelis Permusyawaratan Rakyat Tahun 2001 justru mengadopsi gagasan parlemen bicameral yang bersifat soft. Kedua kamar dewan perwakilan tersebut tidak dilengkapi dengan kewenangan yang sama kuat. Yang lebih kuat tetap DPR, sedangkan kewenangan DPD hanya bersifat tambahan dan terbatas pada hal-hal yang berkaitan langsung dengan kepentingan daerah.

Kedudukan DPD sebagaimana telah dikemukakan di atas, pada hakikatnya tidak sesuai dengan gagasan pembentukan DPD dalam proses reformasi struktur parlemen Indonesia. DPD sebagai lembaga negara tidak memiliki zelfstandigheid atau wewenang mandiri berkaitan dengan pengambilan keputusan hukum dalam menjalankan fungsi legislasi. Berdasarkan Pasal 2 ayat (1) UUD 1945, dengan adanya lembaga baru DPD dalam struktur MPR, maka pengaturan tersebut menganut sistem perwakilan dua kamar (bicameral system). Tetapi pengaturan dalam Pasal 2 ayat (1) ini tidak memberikan ketegasan terhadap pemberlakuan sistem perwakilan dua kamar, dimana MPR terdiri dari anggota DPR dan anggota DPD.

Berbicara mengenai kedudukan DPD sebagai lembaga perwakilan, hal ini tidak mungkin dilepaskan dari konsepsi demokrasi. Dalam konsepsi demokrasi terkandung asas dasar, yakni kedaulatan rakyat menentukan jalannya pemerintahan. Perwujudan asas ini dalam kehidupan pemerintahan sehari-hari tergambar dari keikutsertaan rakyat memutuskan kebijakan-kebijakan pemerintahan. DPD selaku lembaga perwakilan daerah yang memiliki karakter keterwakilan berdasarkan daerah-daerah pada hakikatnya memiliki karakter keterwakilan yang lebih luas dari DPR, karena dimensi keterwakilannya berdasarkan seluruh rakyat yang terdapat pada daerah-daerah tersebut. Untukitu, pengaturan kedudukan DPD yang merupakan lembaga perwakilan

${ }^{12}$ Jimly Asshiddiqie, Konstitusi dan Konstitusionalisme Indonesia, Konstitusi Press, Jakarta, 2005, hlm. 186-187. 
daerah dan berkedudukan sebagai lembaga negara, sebagai perwujudan Pasal 1 ayat (2) UUD 1945, hendaknya merupakan dasar perumusan kedudukan DPD.

\section{Kewenangan Konstitusional Dewan Perwakilan Daerah Sebagai Lembaga Negara}

Dasar normatif pengaturan kewenangan konstitusional DPD diatur dalam Pasal 22D ayat (1), ayat (2), dan ayat (3) UUD 1945. Adapun Pasal 22D ayat (1), ayat (2), dan ayat (3) menyebutkan bahwa:

(1) Dewan Perwakilan Daerah dapat mengajukan kepada Dewan Perwakilan Rakyat rancangan undang-undang yang berkaitan dengan otonomi daerah, hubungan pusat dan daerah, pembentukan dan pemekaran serta penggabungan daerah, pengelolaa sumber daya alam dan sumber daya ekonomi lainnya, serta yang berkaitan dengan perimbangan keuangan pusat dan daerah.

(2) Dewan Perwakilan Daerah ikut membahas rancangan undang-undangan yang berkaitan dengan otonomi daerah; hubungan pusat dan daerah; pembentukan, pemekaran, dan penggabungan daerah; pengelolaan sumber daya alam dan sumber daya ekonomi lainnya, serta perimbangan keuangan pusat dan daerah; serta memberikan pertimbangan kepada Dewan Perwakilan Rakyat atas rancangan undang-undang anggaran pendapatan dan belanja negara dan rancangan undang-undang yang berkaitan dengan pajak, pendidikan, dan agama.

(3) Dewan Perwakilan Daerah dapat melakukan pengawasan atas pelaksanaan undang-undang mengenai; otonomi daerah, pembentukan, pemekaran dan penggabungan daerah, hubungan pusat dan daerah, pengelolaan sumber daya alam dan sumber daya ekonomi lainnya, pelaksanaan anggaran pendapatan dan belanja negara, pajak, pendidikan, dan agama serta menyampaikan hasil pengawasannya itu kepada Dewan Perwakilan Rakyat sebagai bahan pertimbangan untuk ditindaklanjuti.

Dari dasar pengaturan kewenangan konstitusional DPD di atas, DPD memiliki 3 (tiga) fungsi, fungsi legislasi, pertimbangan, dan pengawasan. Ketiga fungsi DPD ini bersifat terbatas, karena pelaksanaan fungsi-fungsi tersebut terbatas pada bidangbidang tertentu saja yang menjadi kewenangan DPD.

Pengaturan fungsi DPD ini pun dijabarkan dalam Pasal 223 ayat (1) UndangUndang Nomor 27 Tahun 2009, yang mengatur bahwa DPD mempunyai fungsi:

a. pengajuan usul kepada DPR mengenai rancangan undang-undang yang berkaitan dengan otonomi daerah, hubungan pusat dan daerah, pembentukan dan pemekaran serta penggabungan daerah, pengelolaan sumber daya alam dan sumber daya ekonomi lainnya, serta yang berkaitan dengan perimbangan keuangan pusat dan daerah;

b. ikut dalam pembahasan rancangan undang-undang yang berkaitan dengan otonomi daerah, hubungan pusat dan daerah, pembentukan, pemekaran dan penggabungan daerah, pengelolaan sumber daya alam dan sumber daya ekonomi lainnya, serta perimbangan keuangan pusat dan daerah; 
c. pemberian pertimbangan kepada DPR atas rancangan undang-undang tentang anggaran pendapatan dan belanja negara dan rancangan undang-undang yang berkaitan dengan pajak, pendidikan, dan agama; dan

d. pengawasan atas pelaksanaan undang-undang mengenai otonomi daerah, pembentukan, pemekaran dan penggabungan daerah, hubungan pusat dan daerah, pengelolaan sumber daya alam dan sumber daya ekonomi lainnya, pelaksanaan APBN, pajak,pendidikan, dan agama.

Selanjutnya pengaturan wewenang DPD diatur secara beriringan dengan tugas DPD yang diatur dalam Pasal 224 sampai dengan Pasal 226, adalah merupakan bagian dari fungsi DPD. Sebagai kelanjutan dari ketiga fungsi tersebut di atas, DPD memiliki tugas dan wewenang secara umum sebagaimana diatur dalam UndangUndang Nomor 27 Tahun 2009, Pasal 224 ayat (1) yang menegaskan sebagai berikut:

a. dapat mengajukan kepada DPR rancangan undangundang yang berkaitan dengan otonomi daerah, hubungan pusat dan daerah, pembentukan dan pemekaran serta penggabungan daerah, pengelolaan sumber daya alam dan sumber daya ekonomi lainnya, serta yang berkaitan dengan perimbangan keuangan pusat dan daerah;

b. ikut membahas bersama DPR dan Presiden rancangan undang-undang yang berkaitan dengan hal sebagaimana dimaksud dalam huruf a;

c. ikut membahas bersama DPR dan Presiden rancangan undang-undang yang diajukan oleh Presiden atau DPR, yang berkaitan dengan hal sebagaimana dimaksud dalam huruf a;

d. memberikan pertimbangan kepada DPR atas rancangan undang-undang tentang APBN dan rancangan undang-undang yang berkaitan dengan pajak, pendidikan, dan agama;

e. dapat melakukan pengawasan atas pelaksanaan undang-undang mengenai otonomi daerah, pembentukan, pemekaran, dan penggabungan daerah, hubungan pusat dan daerah, pengelolaan sumber daya alam, dan sumber daya ekonomi lainnya, pelaksanaan APBN, pajak, pendidikan, dan agama;

f. menyampaikan hasil pengawasan atas pelaksanaan undang-undang mengenai otonomi daerah, pembentukan, pemekaran, dan penggabungan daerah, hubungan pusat dan daerah, pengelolaan sumber daya alam dan sumber daya ekonomi lainnya, pelaksanaan undang-undang APBN, pajak,pendidikan, dan agama kepada DPR sebagai bahan pertimbangan untuk ditindaklanjuti;

g. menerima hasil pemeriksaan atas keuangan Negara dari BPK sebagai bahan membuat pertimbangan kepada DPR tentang rancangan undang-undang yang berkaitan dengan APBN;

h. memberikan memberikan pertimbangan kepada DPR dalam pemilihan anggota BPK; dan

i. ikut serta dalam penyusunan program legislasi nasional yang berkaitan dengan otonomi daerah, hubungan pusat dan daerah, pembentukan dan pemekaran serta penggabungan daerah, pengelolaan sumber daya alam dan sumber daya ekonomi lainnya, serta yang berkaitan dengan perimbangan keuangan pusat dan daerah. 
Kemudian dilanjutkan pada ayat (2)-nya yang menegaskan: Dalam menjalankan tugas pengawasan sebagaimana dimaksud pada ayat (1) huruf e, anggota DPD dapat melakukan rapat dengan pemerintah daerah, DPRD, dan unsur masyarakat di daerah pemilihannya.

Berdasarkan fungsi DPD sebagaimana diuraikan di atas, DPD memiliki kewenangan konstitusional berdasarkan UUD 1945 dan pengaturan lebih lanjut berdasarkan Undang-Undang Nomor 27 Tahun 2009. Sebagai lembaga negara, DPD memiliki kedudukan yang sangat penting berkaitan dengan fungsinya. DPD yang dapat melaksanakan fungsinya merupakan eksistensi DPD sebagai lembaga negara, karena dari fungsi tersebut, menggambarkan adanya suatu lembaga negara tertentu.

Berkaitan dengan pelaksanaan fungsi DPD, maka yang menjadi persoalan adalah berkaitan dengan zelfstandigheid ${ }^{13}$ yaitu wewenang mandiri atau fungsi sepenuhnya dan atau fungsi yang menentukan dari lembaga perwakilan (DPD), baik dari segi perencanaan, penyusunan, pembahasan, sampai pengambilan keputusan. Hal ini dengan sendirinya berkaitan pula dengan kewenangan DPD dalam menjalankan fungsi legislasi, fungsi pertimbangan, dan fungsi pengawasan. Untuk itu, pengkajian terhadap zelfstandigheid DPD ini berkaitan dengan fungsi legislasi termasuk di dalamnya fungsi pertimbangan dan fungsi pengawasan.

Fungsi legislasi DPD berdasarkan Pasal 223 Undang-Undang Nomor 27 Tahun 2009 apabila dibandingkan dengan pengaturan secara substansi norma yang sama sebagaimana dirumuskan Pasal 41 huruf (a) Undang-Undang Nomor 22 Tahun 2003 hanya berkaitan dengan bidang legislasi tertentu. Dalam Penjelasan Pasal 41 huruf (a) menyatakan bahwa: "Yang dimaksud bidang legislasi tertentu dalam hal fungsi pengajuan usul dan ikut membahas rancangan undang-undangan adalah menyangkut rancangan undang-undang yang berkaitan dengan otonomi daerah, hubungan pusat dan daerah, pembentukan dan pemekaran serta penggabungan daerah, pengelolaan sumber daya alam dan sumber daya ekonomi lainnya serta perimbangan keuangan pusat dan daerah. Sedangkan dalam hal fungsi pemberian pertimbangan atas rancangan undang-undang adalah menyangkut anggaran pendapatan dan belanja negara, dan rancangan undang-undang yang berkaitan dengan pajak, pendidikan, dan agama".

${ }^{13}$ Abd. Rahman, "Kedudukan Dan Kewenangan Dewan Perwakilan Daerah (DPD) Dalam Sistem Perwakilan Indonesia”, Ringkasan Disertasi, Program Pascasarjana Universitas Airlangga, Surabaya, 2006, hlm. 33. 
Memperhatikan pengaturan sebagaimana dirumuskan dalam Undang-Undang Nomor 27 Tahun 2009 terdapat fungsi legislasi, fungsi pertimbangan, dan fungsi pengawasan. Fungsi legislasi DPD berkaitan dengan 3 (tiga) bidang tugas, yaitu: 1) mengajukan usul rancangan undang-undang; 2) ikut membahas rancangan undangundang; dan 3) memberi pertimbangan atas rancangan undang-undang. Terhadap fungsi pengawasan berkaitan dengan pengawasan atas pelaksanaan undangundang, sedangkan terhadap fungsi anggaran berkaitan dengan pemberian pertimbangan terhdap rancangan $\mathrm{APBN}$, rancangan undang-undang yang berakaitan dengan pajak, pendidikan, dan agama. ${ }^{14}$

Pengaturan sebagaimana diuraikan di atas menunjukan bahwa ruang lingkup bidang tugas pertama dan kedua mencakup rancangan undang-undang yang berkaitan dengan otonomi daerah, hubungan pusat dan daerah, pembentukan dan pemekaran serta penggabungan daerah, pengelolaan sumber daya alam dan sumber daya ekonomi lainnya, serta perimbangan keuangan pusat dan daerah. Sedangkan ruang lingkup bidang tugas ketiga adalah terbatas pada memberikan pertimbangan atas rancangan undang-undang yang berkaitan dengan pajak, pendidikan, dan agama. Semua bidang tugas DPD tersebut di atas diajukan kepada DPR sebagai pengambil keputusan terakhir.

Ruang lingkup fungsi pengawasan DPD dilakukan terhadap menyampaikan hasil pengawasan atas pelaksanaan undang-undang mengenai otonomi daerah, pembentukan, pemekaran, dan penggabungan daerah, hubungan pusat dan daerah, pengelolaan sumber daya alam dan sumber daya ekonomi lainnya, pelaksanaan undang-undang APBN, pajak,pendidikan, dan agama kepada DPR sebagai bahan pertimbangan untuk ditindaklanjuti, dengan demikian hasil pengawasan yang dilakukan oleh DPD diteruskan kepada DPR sebagai bahan pertimbangan dalam pengambilan keputusan akhir.

Terbatasnya ruang lingkup fungsi dan wewenang yang dimiliki DPD, menyebabkan keberadaan DPD sebagai lembaga negara dalam sistem ketatanegaraan Indonesia merupakan subordinasi dari DPR. Kewenangan DPD dalam UUD 1945 tidak fungsional, karena DPD tidak memiliki "empowering instrument". DPD hanya memiliki kewenangan legislasi yang terbatas sebagaimana diatur dalam Pasal 22D ayat (1) UUD 1945 juncto Pasal 223 ayat (1) Undang-Undang Nomor 27 Tahun 2009 DPD dapat :

\footnotetext{
${ }^{14}$ Ibid., hlm. 34.
} 
a. mengajukan usul kepada DPR mengenai rancangan undang-undang yang berakaitan dengan otonomi daerah, hubungan pusat dan daeran, pembentukan dan pemekaran serta penggabungan daerah, pengelolaan sumber daya alam dan sumber daya ekonomi lainnya, serta yang berkaitan dengan perimbangan keuangan pusat dan daerah.

b. ikut dalam pembahasan rancangan undang-undang yang berkaitan dengan otonomi daerah, hubungan pusat dan daerah, pembentukan, pemekaran dan penggabungan daerah, pengelolaan sumber daya alam dan sumber daya ekonomi lainnya, serta perimbangan keuangan pusat dan daerah;

c. pemberian pertimbangan kepada DPR atas rancangan undang-undang tentang anggaran pendapatan dan belanja negara dan rancangan undang-undang yang berkaitan dengan pajak, pendidikan, dan agama; dan

d. pengawasan atas pelaksanaan undang-undang mengenai otonomi daerah, pembentukan, pemekaran dan penggabungan daerah, hubungan pusat dan daerah, pengelolaan sumber daya alam dan sumber daya ekonomi lainnya, pelaksanaan $\mathrm{APBN}$, pajak, pendidikan, dan agama.

Di samping itu pula, DPD hanya dapat mengajukan rancangan undangundangan pada bidang-bidang tertentu yang berkaitan dengan daerah kepada DPR. Di samping itu pula, DPD pun tidak memiliki kewenangan pembentukan undangundang, tetapi hanya sebagai perancang undang-undang. Hal ini berbeda dengan DPR berdasarkan Pasal 20 UUD 1945 yang memiliki zelfstandigheid pembentukan undang-undang.

Berkaitan dengan kewenangan konstitusional fungsi legislasi DPD dalam hal mengajukan usul rancangan undang-undang berdasarkan UUD 1945, maka frasa “mengajukan kepada DPR" bermakna posisi DPR sebagai lembaga utama pembentuk undang-undang (wetgever) berdasarkan Pasal 20 UUD 1945 dan Presiden sebagai medewetgever ${ }^{15}$ (Pasal 5 ayat (1), dan Pasal 20 ayat (2) sampai dengan ayat (4) UUD 1945). Berkaitan itu pula, DPR dapat dikatakan sebagai organ utama atau primer (primary constitutional organ), sedangkan Presiden merupakan organ pendukung atau penunjang (auxiliary state organ). ${ }^{16}$ Walaupun DPD berdasarkan Pasal 224 ayat (1) Undang-Undang Nomor 27 Tahun 2009 menjalankan fungsi legislasi, tetapi berdasarkan Pasal 22D ayat (1) UUD 1945, DPD tidak berkedudukan sebagai medewetgever atau auxiliary state organ apalagi wetgever atau primary constitutional organ, karena DPD hanya sebatas mengajukan usul rancangan undang-undang, dan tidak sampai pada wilayah pembentukan.

\footnotetext{
${ }^{15}$ Istilah wetgever dan medewetgever dikutip dari pendapat Philipus M. Hadjon dalam Lembaga Tertinggi dan LembagaLembaga Tinggi Negara..., Op.Cit., hlm. 3 dan 17.

${ }^{16}$ Jimly Asshiddiqie, Perkembangan dan Konsolidasi Lembaga Negara..., Op.Cit., hlm. 133.
} 
Bidang tugas DPD dalam fungsi legislasi yaitu ikut membahas rancangan undang-undang merupakan kewenangan konstitusional berdasarkan Pasal 22D ayat (2) UUD 1945. Pengaturan kewenangan konstitusional tersebut berkaitan dengan ayat (1) yang merupakan kewenangan DPD untuk mengajukan usul rancangan undang-undang pada bidang-bidang yang berkaitan dengan otonomi daerah, hubungan pusat dan daerah, pembentukan dan pemekaran serta penggabungan daerah, pengelolaan sumber daya alam dan sumber daya ekonomi lainnya, serta perimbangan keuangan pusat dan daerah. Dasar konstitusional kewenangan DPD ini dalam penjabarannya melalui Pasal 223 ayat (1) dan Pasal 224 ayat (1) UndangUndang Nomor 27 Tahun 2009 tidak sesuai dengan norma pengaturan dalam UUD 1945 dan terjadi tumpang tindih kewenangan.

Rumusan Pasal 223 ayat (1) huruf b Undang-Undang Nomor 27 Tahun 2009 menyebutkan bahwa: “DPD ikut membahas rancangan undang-undang yang berkaitan dengan otonomi daerah, hubungan pusat dan daerah, pembentukan, pemekaran, dan penggabungan daerah, pengelolaan sumber daya alam dan sumber daya ekonomi lainnya, serta yang berkaitan dengan perimbangan keuangan pusat dan daerah yang diajukan baik oleh DPR maupun oleh pemerintah". Rumusan Pasal 224 ayat (1) huruf a, b dan c menyebutkan bahwa:

a. dapat mengajukan kepada DPR rancangan undangundang yang berkaitan dengan otonomi daerah, hubungan pusat dan daerah, pembentukan dan pemekaran serta penggabungan daerah, pengelolaan sumber daya alam dan sumber daya ekonomi lainnya, serta yang berkaitan dengan perimbangan keuangan pusat dan daerah;

b. ikut membahas bersama DPR dan Presiden rancangan undang-undang yang berkaitan dengan hal sebagaimana dimaksud dalam huruf a;

c. ikut membahas bersama DPR dan Presiden rancangan undang-undang yang diajukan oleh Presiden atau DPR, yang berkaitan dengan hal sebagaimana dimaksud dalam huruf a.

Dari rumusan Pasal 223 ayat (1) huruf b di atas jo Pasal 224 ayat (1) huruf b dan c di atas, makna "ikut membahas" diartikan membahas bersama DPR dan Presiden rancangan undang-undang yang bersumber (diajukan) sendiri oleh DPD DPR, dan Presiden. Sedangkan rancangan undang-undang yang bersumber dari DPR dan Presiden, seperti RAPBN, Pajak, Pendidikan, dan Agama dan DPD dalam hal ini diikutkan dalam memberi pertimbangan (Pasal 22D ayat (2) UUD NRI 1945). Adanya penambahan anak kalimat “DPD ikut membahas rancangan undangundang... yang diajukan baik oleh DPR maupun oleh Presiden" dalam Pasal 223 
ayat (1) a ini malah memberikan kewenangan untuk mengajukan rancangan undangundang yang sama kepada 3 (tiga) lembaga negara (DPR, DPD, dan Pemerintah). Hal ini akan menjadi sumber pemicu konflik antara dua atau tiga lembaga negara tersebut di atas.

Berkaitan dengan bidang tugas DPD lainnya dalam fungsi legislasi yaitu "memberi pertimbangan kepada DPR", maka pertimbangan DPD ini lingkupnya hanya mencakup rancangan undang-undang tentang APBN, pajak, pendidikan, dan agama (Pasal 22D ayat (2) UUD 1945). Ketentuan ini pun sangat melemahkan kewenangan konstitusional DPD, karena hanya memberikan pertimbangan kepada DPR mengenai rancangan undang-undang APBN, rancangan undang-undang pajak, pendidikan, dan agama. Padahal, rancangan undang-undang APBN, pajak, pendidikan, dan agama harus dibahas bersama DPD karena bukan saja menyangkut politik negara, tetapi juga kepentingan daerah yang harus diperjuangkan oleh DPD.

Fungsi pengawasan DPD yang merupakan kewenangan konstitusional DPD sebagaimana terdapat dalam Pasal 22D ayat (3) UUD 1945. Kewenangan konstitusional ini kemudian dijabarkan dalam Pasal 223 ayat (1) huruf d juncto Pasal 224 ayat (1) huruf d. Pasal 223 ayat (1) huruf d menyebutkan: "pengawasan atas pelaksanaan undang-undang mengenai otonomi daerah, pembentukan, pemekaran dan penggabungan daerah, hubungan pusat dan daerah, pengelolaan sumber daya alam dan sumber daya ekonomi lainnya, pelaksanaan APBN, pajak,pendidikan, dan agama". Sedangkan Pasal 224 ayat (1) huruf d dan e menentukan sebagai berikut. Huruf d: "dapat melakukan pengawasan atas pelaksanaan undang-undang mengenai otonomi daerah, pembentukan, pemekaran, dan penggabungan daerah, hubungan pusat dan daerah, pengelolaan sumber daya alam, dan sumber daya ekonomi lainnya, pelaksanaan APBN, pajak, pendidikan, dan agama".

Huruf e: "menyampaikan hasil pengawasan atas pelaksanaan undang-undang mengenai otonomi daerah, pembentukan, pemekaran, dan penggabungan daerah, hubungan pusat dan daerah, pengelolaan sumber daya alam dan sumber daya ekonomi lainnya, pelaksanaan undang-undang APBN, pajak,pendidikan, dan agama kepada DPR sebagai bahan pertimbangan untuk ditindaklanjuti";

Rumusan Pasal 224 ini semakin mempertegas bahwa pengawasan dimaksud adalah terkait dengan pelaksanaan undang-undang (ayat (1) huruf d), dengan ruang lingkup sebagaimana diatur dalam ayat (1), sedangkan hasil pengawasan disampaikan kepada DPR untuk ditindaklanjuti (ayat (1) huruf e). 
Sebagaimana telah dikemukakan pada fungsi legislasi sebelumnya, maka dalam fungsi pengawasan ini pun DPD tidak memiliki zelfstandigheid dalam menjalankan fungsi pengawasan. Hal ini terjadi karena hasil-hasil pengawasan DPD tidak dapat ditindaklanjuti sendiri oleh DPD. Hasil-hasil tersebut disampaikan kepada DPR, dan DPR-lah yang menentukan digunakan atau tidak hasil pengawasan tersebut. Fungsi pengawasan DPD ini pun dapat dikatakan tidak memberikan gambaran fungsionalnya DPD sebagai lembaga negara yang memiliki kedudukan sama dengan lembaga negara lainnya.

\section{Penutup}

DPD dalam kedudukannya sebagai lembaga negara yang merupakan lembaga perwakilan daerah, secara kelembagaan memiliki kedudukan yang sama dengan lembaga negara lainnya, seperti MPR dan DPR. Dari kedudukan tersebut, DPD tidak fungsional berkaitan dengan kedudukan dan hubungan-hubungan tersebut. Dalam hubungannya dengan DPR dan MPR, kedudukan DPD sebagaimana diatur dalam UUD 1945 tidak sesuai dengan gagasan pembentukan DPD. Reformasi struktur ketatanegaraan Indonesia menuju sistem perwakilan bikameral yang kuat (strong bicameralism) tidak terwujud dalam UUD 1945. Berdasarkan rumusan Pasal 2 ayat (1) UUD 1945, maka sistem ketatanegaraan Indonesia memiliki sistem perwakilan bikameral yang lemah (soft bicameralism).

Tidak adanya sinkronisasi antara kewenangan konstitusional DPD dengan kedudukan DPD sebagai lembaga negara. Hal ini dilihat pada fungsi DPD terutama pada fungsi legislasi, fungsi pertimbangan, dan fungsi pengawasan, dimana DPD tidak memiliki zelfstandigheid. Dalam fungsi legislasi terutama dalam bidang tugas mengajukan rancangan undang-undang, ikut membahas rancangan undang-undang, dan memberi pertimbangan kepada DPR, DPD tidak bertindak sebagai pembentuk undang-undang, tetapi hanya sebagai lembaga yang mengajukan rancangan undangundang. Sedangkan fungsi pengawasan DPD tidak ditindaklanjuti oleh DPD sendiri, tetapi disampaikan kepada DPR, dan DPR-lah yang menentukan ditindaklanjutinya hasil pengawasan tersebut.

Untuk itu, perlu adanya amandemen terhadap Pasal 2 ayat (1) dan Pasal 22D UUD 1945 berkaitan penegasan sistem perwakilan di Indonesia sebagai "strong bicameral" atau "soft bicameral" dengan adanya DPD yang merupakan lembaga 
perwakilan daerah yang berkedudukan sebagai lembaga negara. Amandemen terhadap Pasal 2 ayat (1) dan Pasal 22D UUD 1945, akan berdampak pada penegasan bahwa kewenangan konstitusional DPD sebagai lembaga negara perwakilan daerah.

\section{Daftar Bacaan}

Amir, Makmur dan Purnomowati, Reni Dewi, Lembaga Perwakilan Rakyat, Pusat Studi Hukum Tata Negara Fakultas Hukum Universitas Indonesia, Jakarta, 2005.

Asshaddiqie, Jimly, Format Kelembagaan Negara dan Pergeseran Kekuasaan Dalam UUD 1945, FH UII Press, Cet. Kedua, Yogyakarta, 2005.

, Konstitusi dan Konstitusionalisme Indonesia, Konstitusi Press, Jakarta, 2005.

, Perkembangan dan Konsolidasi Lembaga Negara Pasca Reformasi, Konstitusi Press, Jakarta, 2006.

Hadjon, Philipus M., Lembaga Tertinggi dan Lembaga-Lembaga Tinggi Negara Menurut Undang-Undang Dasar 1945 Suatu Analisa Hukum dan Kenegaraan, PT Bina Ilmu, Surabaya, 1992.

,"Eksistensi, Kedudukan, dan Fungsi MPR Sebagai Lembaga Negara Dalam Sistem Ketatanegaraan Republik Indonesia", Makalah Seminar Peran MPRRI Pasca Amandemen UUD 1945, yang dilaksanakan oleh Sekretariat Jenderal MPR-RI bekerjasama dengan Fakultas Hukum Universitas Airlangga, di Surabaya, 22 Desember 2005

Jaweng, Robert Endi, et.al., Mengenai DPD-RI Sebuah Gambaran Awal, Institute for Local Development, Jakarta, 2005.

Manan, Bagir, Perkembangan Undang-Undang Dasar 1945, FH UII Press, Yogyakarta, 2004.

Panduan Pemasyarakatan Undang-Undang Dasar Negara Republik Indonesia Sesuai dengan Urutan Bab, Pasal, dan Ayat, Sekretariat Jenderal MPR RI, 2005.

Pieris, John dan Baramuli Putri, Aryanthi, Dewan Perwakilan Daerah Republik Indonesia, Studi, Analisis, Kritik dan Solusi Kajian Hukum dan Politik, Penerbit Pelangi Cendekia, Jakarta, 2006.

Rahman, Abd, "Kedudukan Dan Kewenangan Dewan Perwakilan Daerah (DPD) Dalam Sistem Perwakilan Indonesia", Ringkasan Disertasi, Program Pascasarjana Universitas Airlangga, Surabaya, 2006. 